\section{ECONOMICS}

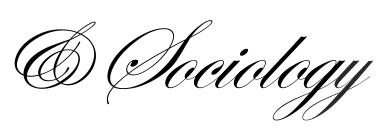

Persson, K. (2019). Confident millennials: Differences in consumer confidence across five generations. Economics and Sociology, 12(4), 257-277. doi:10.14254/2071789X.2019/12-4/16

\title{
CONFIDENT MILLENNIALS: DIFFERENCES IN CONSUMER CONFIDENCE ACROSS FIVE GENERATIONS
}

\author{
Kristoffer Persson, \\ Department of Economics, \\ School of Economics and \\ Management, \\ Lund University, \\ Lund, Sweden, \\ E-mail: \\ kristoffer.persson@nek.lu.se
}

Received: January, 2019 1st Revision: September, 2019 Accepted: December, 2019

DOI: $10.14254 / 2071-$ 789X.2019/12-4/16

\begin{abstract}
This paper investigates if individuals experiencing different socio-economic environments during their formative years have different expectations about future economic conditions. We use Swedish survey data to analyse differences in expectations across five generations of consumers by testing if they have different levels of confidence. The paper focuses on all the different generations of the 1900s as defined by Howe and Strauss (1997, 2000). In our econometric model, we use the Millennial Generation as a baseline, as this generation is about to make up the largest fraction of consumers in the economy. Contrary to the theory developed by the literature on generations, such as Howe and Strauss, our results show that confidence increases gradually across generations. We find that the Millennials are more confident than generations born in the first half of the 1900 s, but similar in confidence to other generations born in the second half of the 1900s.
\end{abstract}

Keywords: generations, socio-economic environment, economic behavior, economic change, Scandinavia.

\section{Introduction}

Expectations are essential for explaining economic behaviour (e.g. Keynes, 1936; Lachmann, 1943; Muth, 1961). They influence individuals' decisions in terms of savings and consumption (Brown \& Taylor, 2006, Moretti, 2011), entrepreneurial endeavours (Arenius \& Minniti, 2005; Koellinger et al., 2007) and investments in financial assets (Baker and Wurgler, 2007; Burnside et al., 2011; Hirshleifer, 2001). When individuals are overconfident, their expectations may be unrealistically optimistic and can thus cause financial bubbles to inflate and burst, leading to economic recessions (Duca et al., 2010; Gan, 2007; Schularick \& Taylor, 2012). The effect of expectations on the economy is not, however, limited to major downturns caused by financial bubbles. Business cycle dynamics is continuously affected by consumers' expectations about future economic developments. These expectations develop in waves of optimism and pessimism, affecting aggregate economic variables (Matsusaka \& Sbordone, 1995; Taylor \& McNabb, 2007). Broad changes in the levels of optimism and pessimism in society are therefore likely to have an effect on the economy and may arise as a consequence of demographic and social change occurring when the relative composition of generations in society shifts (Mannheim, 1952; Pilcher, 1994). This topic has, however, received relatively limited attention in the economic literature. One obstacle is obtaining 
consistent data spanning several decades, making it difficult to separate generation effects from time-specific effects that stem from macroeconomic shocks and individual specific effects like age, income and gender.

In this study, we use data from the Swedish survey on households' purchasing plans (Hushållens inköpsplaner) from 1978 to 2015 to study generational differences in terms of expectations about future economic developments. In our analysis, we use the generational theory following, for example, Howe and Strauss (1997, 2000). This theory is developed for the USA and defines generations as cohorts of individuals that have shared experiences of major events during their formative years. Most of these events, however, are international, for instance, WW2 and the Great Depression, and are thus likely to affect individuals in many other developed economies to a similar extent as they affect Americans.

The literature on generations emphasizes the importance of early-life experiences because these are likely to shape peoples' attitudes and beliefs (Kupperschmidt, 2000; Schaie, 1965). Generational cohorts grow up in different macroeconomic environments and may thus, on average, differ in attitudes and beliefs that are relevant for economic outcomes. People growing up during the Great Depression, for example, are considered risk averse and pessimistic about future economic conditions (Malmendier \& Nagel, 2011). Other generations, such as the Baby Boomer Generation, experienced different economic conditions, such as the absence of economic crisis and war, as well as a good economic climate. This may have caused the Boomers to have low levels of risk aversion and an optimistic outlook on future economic developments (Baek \& DeVaney, 2004).

Equally as large as the Baby Boomers, or in some countries, even larger, is the Millennial Generation, which was born between 1985 and 2000 (Schewe et al., 2013). They experienced a similar macroeconomic environment as the Baby Boomers during their formative years, but may have different attitudes because they grew up in a world of computers, mobile phones and the Internet. It is thus possible that this unique environment has caused the Millennials to be more confident, optimistic and narcissistic than other generations (Bourke \& Mechler, 2010; Gardner \& Macky, 2012). As the Millennial Generation enters adult life, replacing the Baby Boomers, the relative composition of generations in society is about to change, possibly impacting the economy.

Some are worried that the Millennial Generation, with their potentially unique characteristics, will clash with other generations and thereby create a more volatile workplace (Myers and Sadaghiani, 2010). Others see potential benefits, such as increased flexibility of the labour force and more entrepreneurship (Levenson, 2010). The impact of the Millennials on economic expectations has not been studied to the same extent. This paper applies tests of consumer confidence to sentiment data for all generations of the 1900s, including the Millennials.

The survey data that we use is collected on a quarterly/monthly frequency. With nearly 40 years of observations, we observe the attitudes of five generations: the Greatest Generation, the Silent Generation, the Baby Boomer Generation, Generation X and the Millennial Generation. This gives us unique possibilities in relation to other generational studies which are typically limited to a few generations, each measured at different points in time (e.g. Levenson, 2010). Our results show that generations are gradually becoming more confident. Individuals born in the first half of the 1900s are less confident than individuals born in the second half. Generations are increasingly confident, starting with the Baby Boomer Generation, a trend which levels off with the arrival of the Millennials. This indicates that the economy has moved from a low level of confidence to a new and higher level of confidence.

The rest of the paper is organized as follows: section 1 develops hypotheses on the differences among generations' expectations. Section 2 presents the data and measurements. 
Section 3 presents descriptive statistics, section 4 presents the econometric model and the results, section 5 presents robustness checks and section 6 concludes the paper.

\section{Generations, beliefs and attitudes: Four hypotheses}

Two aspects are pivotal for a group to be regarded as a generation. First, individuals share similar early-life experiences which have major impacts on society as a whole and may be of a socio-economic nature, such as wars and economic depressions (Kupperschmidt, 2000). They may also be of a technological nature, such as the emergence of the automobile or the Internet (Crampton and Hodge, 2009). Second, experiences occur when individuals are at a similar age; adolescence and young adulthood are particularly important (Mannheim, 1952; Twenge et al., 2010).

Major events experienced during young adulthood are likely to make a stronger impression than events occurring later in life (Malmendier \& Nagel, 2016; Schuman \& Scott, 1989; Stewart \& Healy, 1989). A potential reason for this is that young individuals' life circumstances become less constrained as they move away from home. This gives them the opportunity to explore different world views and a broad range of life experiences. Young individuals typically do this by, for example, attending university and exploring different career paths. As they approach the end of young adulthood, their life circumstances are again more constrained, as they settle down, with many starting a family (Arnett, 2000). This may reduce individuals' possibilities for taking in additional worldviews and experiences. As a result, early-life experiences may equip individuals with a natural view of the world that stays throughout the rest of their lives (Scott, 2000).

Howe and Strauss $(1997,2000)$ identify five generations in developed countries during the 1900s. The Greatest Generation, GI, was born approximately between 1901 and 1924, and they experienced the Great Depression as adolescents and young adults and fought during World War 2 (WW2). The Silent Generation, GS, was born approximately between 1925 and 1945, and experienced the years following the Great Depression and the rationing and hardships of WW2 during their formative years. This generation is described as disciplined, consistent and hardworking, with traditional values (Crampton \& Hodge, 2009). Because they share similar experiences as GI, they are sometimes bundled together with this generation (Smola \& Sutton, 2002).

The Baby Boomer Generation, BB, consists of individuals born during the years 1946-1965. They grew up during times of economic expansion and experienced the Vietnam War and a range of social changes, such as the civil rights movement in the United States (Kupperschmidt, 2000). Boomers are typically described as self-confident and having a positive outlook on economic outcomes (Gardner \& Macky, 2012; Levenson, 2010). Generation X, GX, are born approximately between 1965 and 1985. This generation experienced unsettling macroeconomic conditions during their formative years, such as the oil crises of the 1970s and increasing national deficits, especially in the US. This generation is described as pragmatic and cautious about economic decisions (Gardner \& Macky, 2012; Levenson, 2010).

Finally, we have the Millennial Generation, MG, sometimes called Generation Y. Most scholars define the MG as individuals born approximately between the early to mid1980s and mid-1990s to the early 2000s. During their formative years, they experienced stable economic conditions in a social environment characterized by individualism (Twenge, 2009). The generation experienced an unprecedented growth of fast and easy communication via the emergence of the Internet and the mobile phone, leading to new technological phenomena such as search engines and social media (Hershatter \& Epstein, 2010). Some suggest that this development has caused the MGs' brains to develop differently from 
previous generations, with more developed cognitive strategies for finding correct information (Mills, 2014), while others find no effects of early-life exposure to these new technologies on the MGs' approach to technology later in life (Ayala-Perez, 2019). MGs' formative years may, on the whole, have caused the generation to be self-confident, selfcentred and optimistic (Bourke \& Mechler, 2010; Gardner \& Macky, 2012). Table 1 compiles generations' early-life economic environments, major events and characteristic traits.

Table 1. Swedish generations 1901-2015

\begin{tabular}{|c|c|c|c|c|c|c|}
\hline & $\begin{array}{l}\text { Formative } \\
\text { Years }\end{array}$ & $\begin{array}{l}\text { Average } \\
\text { Annual } \\
\text { GDP } \\
\text { Growth }\end{array}$ & $\begin{array}{l}\text { Average } \\
\text { Annual } \\
\text { CPI } \\
\text { Change }\end{array}$ & $\begin{array}{l}\text { Wars and } \\
\text { Sustained } \\
\text { Recessions }\end{array}$ & $\begin{array}{c}\text { Major Social and } \\
\text { Technological Events }\end{array}$ & $\begin{array}{c}\text { Characteristic } \\
\text { Traits }\end{array}$ \\
\hline \multirow{5}{*}{ GI } & 1916-1918 & -6.49 & 32.69 & WW1 & \multirow{5}{*}{$\begin{array}{l}\text { Threat of Revolution, } \\
\text { Democratization }\end{array}$} & \multirow{5}{*}{$\begin{array}{l}\text { Disciplined, } \\
\text { Dutiful, } \\
\text { Hardworking, } \\
\text { Risk-Averse }\end{array}$} \\
\hline & $1918-1920$ & 5.64 & 11.98 & - & & \\
\hline & $1920-1921$ & -8.51 & -18.05 & $\begin{array}{l}\text { Anti-Inflation } \\
\text { policy }\end{array}$ & & \\
\hline & $1921-1924$ & 7.05 & -9.58 & - & & \\
\hline & 1924-1925 & 0.58 & 0.94 & - & & \\
\hline \multirow{5}{*}{ GS } & $1925-1930$ & 5.05 & -2.79 & - & \multirow{5}{*}{ Automobile, Radio } & \multirow{5}{*}{$\begin{array}{l}\text { Disciplined, } \\
\text { Dutiful, } \\
\text { Hardworking, } \\
\text { Risk-Averse }\end{array}$} \\
\hline & $1930-1932$ & -2.07 & -4.36 & $\begin{array}{c}\text { Great } \\
\text { Depression }\end{array}$ & & \\
\hline & 1932-1939 & 5.27 & 1.92 & - & & \\
\hline & $1939-1941$ & -5.48 & 15.11 & WW2 & & \\
\hline & $1941-1952$ & 3.89 & 4.76 & $\begin{array}{l}\text { Cold War, } \\
\text { Korean War }\end{array}$ & & \\
\hline \multirow{2}{*}{ BB } & $1952-1953$ & 0.70 & 1.66 & Cold War, & \multirow{2}{*}{$\begin{array}{l}\text { Space Race, TV, Civil } \\
\text { Rights Movement }\end{array}$} & \multirow{2}{*}{$\begin{array}{l}\text { Self-Confident, } \\
\text { Optimistic }\end{array}$} \\
\hline & $1953-1976$ & 3.98 & 5.11 & Vietnam War & & \\
\hline \multirow{6}{*}{ GX } & 1976-1978 & -0.79 & 11.2 & Oil Crisis & \multirow{6}{*}{$\begin{array}{l}\text { Cheap Aviation and } \\
\text { Increased Travel }\end{array}$} & \multirow{6}{*}{$\begin{array}{l}\text { Agreeable, Risk- } \\
\text { Averse, Self- } \\
\text { Centred }\end{array}$} \\
\hline & $1978-1979$ & 3.20 & 7.95 & & & \\
\hline & $1979-1981$ & 0.09 & 12.25 & Cold War & & \\
\hline & 1981-1990 & 2.30 & 7.76 & & & \\
\hline & $1990-1993$ & -1.68 & 6.08 & $\begin{array}{c}\text { Housing } \\
\text { Bubble } \\
\text { Followed by } \\
\text { Financial } \\
\text { Crisis } \\
\end{array}$ & & \\
\hline & $1993-2000$ & 3.47 & 1.57 & - & & \\
\hline \multirow{3}{*}{ MG } & $2000-2008$ & 2.59 & 1.71 & War on Terror & \multirow{3}{*}{$\begin{array}{c}\text { Mobile } \\
\text { Telecommunications, } \\
\text { Internet and IT, Social } \\
\text { Media }\end{array}$} & \multirow{3}{*}{$\begin{array}{l}\text { Self-Confident, } \\
\text { Self-Centred, } \\
\text { Optimistic }\end{array}$} \\
\hline & 2008-2009 & -5.23 & 0.50 & $\begin{array}{c}\text { Great } \\
\text { Recession } \\
\end{array}$ & & \\
\hline & $2009-2015$ & 2.79 & 0.66 & War on Terror & & \\
\hline
\end{tabular}

Average annual GDP/CPI growth in Sweden until 2000 is taken from Edvinsson (2005). Grey cells mark years of economic depression, defined as an event when volume GDP in one year is below the level of volume GDP two years earlier, and consists of the negative consecutive annual changes in volume GDP. White cells are either years of economic expansion or mini-recessions. Post-2000 data are collected from Statistics Sweden and calculated by the author.

Table 1 shows that some generations experienced different socio-economic environments during their formative years than others. Some generations, such as GI, GS and GX, experienced periods of sustained recessions as defined by Edvinsson (2005), coupled with high inflation around the time of WW1, WW2, the oil crisis of the 1970s and economic crisis of the early 1990s. Others, like BB and MG, grew up in stable economic environments 
with steady growth and an absence of major and long-lasting economic downturns. ${ }^{i}$ This suggests that some generations, although having experienced critical events at different times, are more similar than others. This brings us to our first hypothesis:

H1: The GI, GS and GX generations are similar, having lower economic confidence than the $\mathrm{BB}$ and $\mathrm{MG}$ generations.

The personal traits ascribed to the MG are debatable. Some argue that they are not different from previous generations, since studies that find differences between MG and other generations fail at disentangling age, cohort and time-specific effects (Gardner and Macky, 2012; Levenson, 2010). Others argue that the MG have a set of distinct attributes that set them aside from previous generations. They are described as confident and positive (Martin and Tulgan, 2001), narcissistic (Bourke and Mechler, 2010), ambitious (Twenge, 2009) and having a strong sense of entitlement (Kelly, 2010). These traits can be related to behavioural heuristics and biases (Gardner and Macky, 2012; Nga and Yien, 2013). Overconfidence, i.e., overestimating one's own ability in relation to others, increases when one is narcissistic and has a positive outlook on life (Meisel et al., 2016; Schaefer et al., 2004; Schrand and Zechman, 2012).

Some suggest that the Swedish MG may be different from MGs in other developed countries as they will have experienced some events that are unique to Sweden (Schewe et al., 2013). Many of these events are not, however, likely to affect the generation's economic confidence. ${ }^{\mathrm{ii}}$ Others point out that the Swedish economy and society have become more market-oriented since the 1980s, causing the Swedish MG to be more individualistic than previous generations (Allvin and Sverke, 2000). This development should, if anything, bring the Swedish MG closer to other developed countries such as the USA in terms of attitudes and beliefs that are relevant for economic confidence. This brings us to our second hypothesis:

H2: The MG is more confident about economic developments than all other generations.

Changes in confidence across generations are likely to be gradual. Generations overlap with each other and can therefore transfer some of their values and beliefs onto later generations. The impact of major events on the values and beliefs of one generation can therefore also be present for generations that follow. This causes generations to change gradually despite having experienced different major socio-economic environments during their formative years (Mannheim, 1952). This brings us to our third hypothesis:

H3: Economic confidence changes gradually from one generation to the next.

It is possible that later-life experiences matter for individuals' attitudes and beliefs. Important personality traits may also develop later in life, as individuals tend to become more agreeable, conscious and less neurotic with age (Caspi and Roberts, 2001; Srivastava et al., 2003). This is likely to have a stabilizing effect on expectations about future economic developments. However, there is also evidence indicating that attributes related to consumer confidence are less likely to change during a lifetime. Individuals' financial risk-taking decisions are affected more by early-life experiences than experiences occurring later in life. These decisions are affected both by changed risk preferences and optimism about the future (Malmendier and Nagel, 2011). CEOs belonging to GI and GS are consequently less overconfident in corporate financing decisions throughout their lives than others (Malmendier et al., 2011). This brings us to our fourth hypothesis: 
H4: Individuals exhibit a life-cycle pattern in economic confidence, irrespective of the generation to which they belong.

\section{Data and measurements}

Consumer sentiment data is a popular way to measure economic expectations. This data is usually collected by statistics agencies using surveys that ask consumers, households and professionals about their opinions of future economic developments (Manski, 2004). Very few of these surveys are conducted over long time periods, making it difficult for researchers to use them for measuring differences in people's expectations depending on their early-life experiences. We use survey data from Swedish households, which has been collected on a quarterly and monthly basis since 1978 . ${ }^{\text {iii }}$ The data's micro structure allows us to identify the respondents' generations by their birth date, which includes individuals born in the early 1900s. This allows us to divide respondents into groups corresponding to the generations presented in Table 1. The survey asks respondents about their consumption of durables and housing, as well as their opinions regarding their own and nationwide economic developments. We utilize the following questions for analysing generations' confidence levels about future economic conditions:

Q1: "How do you expect your economic situation to develop during the next 12 months?"

Q2: "How do you expect the Swedish economic situation to develop over the next 12 months?"

Q3: "How has your personal economic situation developed during the past 12 months?"

Q4: "How has the Swedish economic situation developed during the past 12 months?"

Q5: "How do you think unemployment in Sweden will develop during the next 12 months?"

Respondents are given the following options when answering Q1-Q5:

A1: "worse/increase (in relation to 12 months ago/today)"

A2: "the same (in relation to 12 months ago/today)"

A3: "better/decrease (in relation to 12 months ago/today)"

A4: "I don't know"

Answers are coded with integers ranging from 1 to 4 according to the indexation above. We use this survey data to measure individuals' confidence in two different ways. The first way follows Matsusaka and Sbordone (1995) and entails calculating a consumer confidence index by averaging across respondents' answers to a set of questions regarding future and current economic conditions. The second way follows Bovi (2009) and entails i) calculating individuals' confidence about their own economic situation relative to that of the nationwide economic situation, allowing us to capture if individuals are overconfident about their own economic situation in relation to others, and ii) calculating individuals' confidence about future economic conditions in relation to past perceived economic conditions, allowing us to capture if individuals are overoptimistic about the future relative to the past. Table 2 summarizes the different measurements that we use. 
Table 2. Confidence measures

\begin{tabular}{ccc}
\hline Name & Measure & Calculation \\
\hline Measure 1 & Consumer confidence index & $\begin{array}{c}\text { Average of answers to: Q1, Q2, } \\
\text { Q3, Q5. }{ }^{\text {iv }}\end{array}$ \\
\hline Measure 2 & $\begin{array}{c}\text { The future state of the } \\
\text { households' economic situation } \\
\text { in relation to the future state of } \\
\text { the nationwide economy. }\end{array}$ & Q1-Q2 \\
Measure 3 & $\begin{array}{c}\text { The future state of the } \\
\text { households' economic situation } \\
\text { in relation to its past } \\
\text { development. }\end{array}$ & Q1-Q3 \\
\hline Measure 4 & The future state of the \\
& nationwide economy in relation \\
to its past development.
\end{tabular}

If the average of Measure 1 is smaller than 2, then more respondents on average report A1 rather than $\mathrm{A} 2$ and $\mathrm{A} 3$ to Q1, Q2, Q3 and Q5. This means that the respondents are pessimistic about economic conditions. If the average of Measure 1 is equal to 2, then respondents on average answer A2 to Q1, Q2, Q3 and Q5 which means that they are neutral in their opinion about current economic conditions. If the average of Measure 1 is greater than 2, then most respondents have reported A3 rather than A2 or A1 to Q1, Q2, Q3 and Q5, which means that they are on average optimistic about economic conditions. This measure allows us to capture whether generations are on average optimistic, pessimistic or neutral about economic conditions.

If the average of Measure 2 is equal to zero, then respondents report the same answer to Q1 and Q2, which means that they are on average equally confident about the future of their own economic situation and the nationwide situation. If the average of Measure 2 is greater than zero, then most respondents reply A3 to Q1 and A2 or A1 to Q2, or they reply $\mathrm{A} 2$ to $\mathrm{Q} 1$ and $\mathrm{A} 1$ to $\mathrm{Q} 2$. Consumers are then more confident about the future of their own economic situation than the nationwide situation, on average. This indicates that respondents are overconfident because they are likely to suffer from the illusion of control bias which is an integral part of overconfidence (Bovi, 2009). If the average of Measure 2 is smaller than zero, then most respondents on average reply A1 to Q2 and A3 or A2 to Q1, or they reply A2 to $\mathrm{Q} 2$ and $\mathrm{A} 3$ to $\mathrm{Q} 1$. This means that consumers are less confident about the future of their own economic situation than the nationwide situation.

If the average of Measure 3 is equal to zero, then the average number of respondents answer the same for Q1 and Q3, meaning that consumers are equally confident about the future of their own personal economic situation compared to its past developments. If the average of Measure 3 is smaller than zero, then respondents on average reply A3 to Q3 and $\mathrm{A} 2$ or $\mathrm{A} 1$ to $\mathrm{Q} 1$, or they reply $\mathrm{A} 2$ to $\mathrm{Q} 3$ and $\mathrm{A} 1$ to $\mathrm{Q} 1$. This means that consumers are less confident about the future of their own personal economic situation compared to its past development. If the average of Measure 3 is greater than zero, then the average respondent replies A3 to Q1 and A2 or A1 to Q3, or replies A2 to Q1 and A1 to Q3. This means that consumers are more confident about the future of their own personal economic situation compared to its past state. Measure 4 works similarly to Measure 3, with the exception that the measure regards respondents' opinions about the nationwide economy instead of their own personal economic situation. If these averages are greater than zero, then respondents are consistently optimistic about future economic conditions relative to past perceived economic outcomes. Given the business cycle-like nature of consumer confidence as measured by 
consumer confidence surveys, this indicates that individuals are unrealistically optimistic about future economic developments because it would be more realistic for individuals to expect that future economic conditions are equal to past economic conditions, on average.

The questionnaire gives six different possible answers to Q1-Q5 during 1992-2016. The difference to the 1978-1992 period is that A1 and A3 are divided into two answers that indicate how strong the respondents estimate developments to be. We harmonize the data by recoding the answers to fit the description above (A1-A4). Positive answers (i.e. "somewhat better" and "a lot better") are coded as A3, and the negative answers are likewise recoded as A1. In our analysis, we remove observations with observations that are neutral (A2) for all questions included in our measures, and all observations which contain at least one instance of A4 (i.e. I don't know). The reason for this is that i) it is probable that neutral answers indicate that respondents have not answered truthfully to the questions (Krosnick and Fabrigar, 1997; Chyung et al., 2017), and ii) to ensure that we can compute all of our measures for each individual in the data. This is likely to improve the quality of the data we use in our analysis and thus render more reliable estimates of different generations' confidence. The questionnaire asks respondents about Q4 for the period 1994-2015. Since the data contains information about respondents' education level from 1992 onwards, we fill the gap by using data on the average level of years in education from Ljungberg and Nilsson (2009). The survey asks respondents about income information at a more granular level for sample period one than for sample period two. We harmonize the information by mapping each of the 12 income intervals of the first sample period to the four wider income intervals that exist for the second sample period.

\section{Descriptive Statistics}

In this section, we explore the survey data by using descriptive statistical methods in order to get a general picture of different generations in terms of our confidence measures. In the following section, we test our hypotheses formally using a linear regression model where we include control variables for age, education, income, gender and time fixed effects. Table 3 presents the samples we use for calculating our measures.

Table 3. Generation samples

\begin{tabular}{ccccc}
\hline & Birth year & Start of Sample & End of Sample & Obs. \\
\hline GI & $1900-1924$ & 1978 & 1992 & 29,776 \\
\hline GS & $1925-1944$ & 1978 & 2001 & 50,522 \\
\hline BB & $1945-1964$ & 1978 & 2015 & 134,200 \\
\hline GX & $1965-1984$ & 1994 & 2015 & 147,758 \\
\hline MG & $1985-2000$ & 2006 & 2015 & 9,316 \\
\hline
\end{tabular}

The $\mathrm{BB}$ is the best represented generation in the data with 134,200 observations covering the full sample period from 1978 to 2015 . However, the GX is the largest sample in the data with 147,758 observations during 1994-2015. The reason for the GX having more observations than the BB is i) that the sampling frequency increased in 1992 from quarterly to monthly, and ii) that the size of the GX in relation to the BB has increased in the population from 1994 and onwards. In our sample, we may theoretically observe the first individuals that belong to the GX in 1984 when individuals born in 1965 are 19 years old, which was the minimum age for participation in the survey before 1992. The reason why our GX sample starts in 1994 is that there are no members of the GX in the data who give complete answers to the set of questions we use in our measures before 1994. This is likely due to the fact that the GX initially constitute a small share of the total number of respondents in the survey. 
The MG is the smallest sample in the data with 9,316 observations. Millennials may, theoretically, enter our sample in 2001 when they are 16 years old, which is the minimum age for participation in the survey after 1992. The reason why our sample starts in 2006 is that we use the midpoint of 15-, 20- and 10-year age intervals to calculate respondents' birth date for all observations which are collected after 1992. This may cause some measurement error as Millennials born in, for example, 1985 are registered as members of GX in 2001. This, however, is not likely to cause any major issues in our analysis since Millennials who are misclassified as members of the GX are likely to be few in relation to individuals who are correctly classified as members of the GX. Table 4 presents mean confidence levels for our five measurements for each generation in the sample, while Table 5 presents p-values of tests of significant differences in means across generations. Table 6 presents mean confidence levels for generations across ages.

Table 4. Mean consumer confidence across generations

\begin{tabular}{ccccc}
\hline & Measure 1 & Measure 2 & Measure 3 & Measure 4 \\
\hline \multirow{2}{*}{ GI } & 1.86 & 0.07 & 0.02 & - \\
& $(0.33)$ & $(0.77)$ & $(0.50)$ & 0.06 \\
\multirow{2}{*}{ GS } & 1.94 & 0.14 & 0.06 & $(0.86)$ \\
& $(0.4)$ & $(0.75)$ & $(0.79)$ & 0.1 \\
\multirow{2}{*}{ BB } & 2.15 & 0.14 & 0.06 & $(0.89)$ \\
\hline \multirow{2}{*}{ GX } & $(0.47)$ & $(0.83)$ & $(0.72)$ & 0.16 \\
& 2.37 & 0.21 & 0.15 & $(1.01)$ \\
\hline \multirow{2}{*}{ MG } & $(0.49)$ & $(0.91)$ & $(0.88)$ & 0.27 \\
& 2.5 & 0.20 & 0.22 & $(1.11)$ \\
\hline
\end{tabular}

Standard deviation to the mean presented in brackets. Measure 4 is not available for the GI because Q4 is introduced in 1994 when respondents that belong to the GI are no longer represented in the sample.

Reporting on the descriptive statistics presented in Table 4, we note that the GI and GS generations are on average pessimistic about the future development of their own economic situation and the nationwide economy. However, the BB, GX and MG generations are confident, with the MG being the most confident of all generations in the sample. The average of Measure 3 is positive for all generations and increasing across generation cohorts. The GI has a mean which is half of that of the GS and the BB. The GX suffers more on average from Measure 2 bias and is similar to the MG. The average extent to which the GI is affected by Measure 3 is the lowest of all generations. The averages for GS and BB are again similar. The MG has the highest mean in all measurements, with the exception of Measure 3. The average level of GX across measurements is more than $40 \%$ lower than that of the MG, while averages for the BB and GS are even lower. 
Table 5. Tests of differences in generations' confidence

\begin{tabular}{|c|c|c|c|c|}
\hline Measure 1 & GI & GS & $\mathrm{BB}$ & GX \\
\hline GS & 0.00 & & & \\
\hline BB & 0.00 & 0.00 & & \\
\hline GX & 0.00 & 0.00 & 0.00 & \\
\hline MG & 0.00 & 0.00 & 0.00 & 0.00 \\
\hline Measure 2 & GI & GS & $\mathrm{BB}$ & GX \\
\hline GS & 0.00 & & & \\
\hline $\mathrm{BB}$ & 0.00 & 0.50 & & \\
\hline GX & 0.00 & 0.00 & 0.00 & \\
\hline $\mathrm{MG}$ & 0.00 & 0.00 & 0.00 & 0.00 \\
\hline Measure 3 & GI & GS & $\mathrm{BB}$ & GX \\
\hline GS & 0.00 & & & \\
\hline BB & 0.00 & 0.00 & & \\
\hline GX & 0.00 & 0.00 & 0.00 & \\
\hline $\mathrm{MG}$ & 0.00 & 0.00 & 0.00 & 0.00 \\
\hline Measure 4 & GI & GS & BB & GX \\
\hline \multicolumn{5}{|l|}{ GS } \\
\hline BB & & 0.28 & & \\
\hline GX & & 0.00 & 0.00 & \\
\hline $\mathrm{MG}$ & & 0.02 & 0.00 & 0.00 \\
\hline
\end{tabular}

P-values resulting from the standard t-test of difference in means.

The p-values presented in Table 5 show that most generations are statistically different from each other at a $1 \%$ level. The GS and the BB generations are not, however, significantly different in two of the four measurements. Subsequently, we investigate the evolution of confidence across ages.

Table 6. Mean confidence across generations and ages

\begin{tabular}{|c|c|c|c|c|c|c|c|}
\hline Measure 1 & $16-25$ & $26-35$ & $36-45$ & $46-55$ & $56-65$ & $66-70$ & $70+$ \\
\hline GI & & & & & 1.88 & 1.85 & 1.85 \\
\hline GS & & & 1.89 & 1.91 & 1.97 & 1.9 & \\
\hline BB & 2.05 & 2.01 & 2.09 & 2.25 & 2.12 & & \\
\hline Measure 1 & $19-29$ & $30-49$ & $50-64$ & $65+$ & & & \\
\hline GX & 2.45 & 2.37 & 2.25 & & & & \\
\hline MG & 2.5 & & & & & & \\
\hline Measure 2 & $16-25$ & $26-35$ & $36-45$ & $46-55$ & $56-65$ & $66-70$ & $70+$ \\
\hline GI & & & & & 0.09 & 0.04 & 0.11 \\
\hline GS & & & 0.17 & 0.16 & 0.12 & 0.19 & \\
\hline BB & 0.17 & 0.31 & 0.21 & 0.11 & -0.03 & & \\
\hline Measure 2 & $19-29$ & $30-49$ & $50-64$ & $65+$ & & & \\
\hline GX & 0.12 & 0.23 & 0.21 & & & & \\
\hline $\mathrm{MG}$ & 0.2 & & & & & & \\
\hline Measure 3 & $16-25$ & $26-35$ & $36-45$ & $46-55$ & $56-65$ & $66-70$ & $70+$ \\
\hline GI & & & & & 0.05 & 0.02 & 0.01 \\
\hline GS & & & 0.05 & 0.08 & 0.03 & -0.07 & \\
\hline $\mathrm{BB}$ & -0.04 & 0.03 & 0.09 & 0.03 & -0.02 & & \\
\hline Measure 3 & $19-29$ & $30-49$ & $50-64$ & $65+$ & & & \\
\hline GX & 0.16 & 0.18 & 0.04 & & & & \\
\hline MG & 0.22 & & & & & & \\
\hline Measure 4 & $19-29$ & $30-49$ & $50-64$ & $65+$ & & & \\
\hline \multicolumn{8}{|l|}{ GI } \\
\hline GS & & & & 0.06 & & & \\
\hline $\mathrm{BB}$ & & 0.12 & 0.07 & 0.19 & & & \\
\hline GX & 0.08 & 0.13 & 0.27 & & & & \\
\hline $\mathrm{MG}$ & 0.27 & & & & & & \\
\hline
\end{tabular}


Average confidence levels of measures 1-4 calculated for each generation and age interval. The age intervals are different across generations and measures. A majority of the GI, GS and BB are measured before 1994 when the survey placed respondents into 6 different age intervals while the GX and MG are measured after 1994 when the survey placed respondents into 4 different age intervals. Q4 was introduced in 1994 and Measure 4 is thus measured when the survey placed respondents into 4 different age intervals.

The BB is the best represented generation in the sample, covering all ages until retirement (age 65). Table 6 shows that their confidence follows a clear pattern. Early-life averages are lower in relation to midlife averages, and in older age, the average confidence again drops. Other generations, however, do not follow this pattern to the same extent. The GS, for example, does not show any clear pattern in the development of Measure 2. Averages for this measure and generation are located in the range of 0.12 for ages 55-65 to 0.19 for ages 66-70. Developments of average confidence levels are increasing across generations for ages 16-25, 26-35 and 36-45 for all confidence measurements.

\section{Econometric model and results}

Subsequently, we test for differences among the generations in a set of regression models where we include control variables for age, education, income and gender. The model includes time-fixed effects to control for contemporaneous exogenous shocks affecting most individuals, such as sudden changes in the oil price, changes in monetary policy regime and changes in financial regulations. We split each generation cohort into two parts in our model. This allows us to capture more granular changes than the generation demarcation stemming from, for example, the work of Howe and Strauss (1997). It is also flexible with regards to differences in major events affecting only individuals in Sweden, potentially affecting Swedish generations differently than those of other developed countries. We deploy a least square dummy variable (LSDV) estimation for the four different measurements: ${ }^{\mathrm{v}}$

$$
\begin{aligned}
& \text { confidence }_{i, t}=\alpha+\sum_{c=1}^{8} \beta_{c} D_{i, t}^{\text {cohort }_{c-1}}+\sum_{a=9}^{16} \beta_{a} D_{i, t}^{\text {age }}+\beta_{17} D_{i, t}^{\text {gender }_{0}}+ \\
& \sum_{k=18}^{21} \beta_{k} D_{i, t}^{\text {income }_{k-18}}+\sum_{e=22}^{24} \beta_{e} D_{i, t}^{\text {education }} \text {-22 }+ \\
& \sum_{d=25}^{27} \beta_{d} D_{i, t}^{\text {datacollector }} d-25+\sum_{y=28}^{64} \beta_{y} D_{i, t}^{\text {year }_{y-28}}+\varepsilon_{i, t}
\end{aligned}
$$

Where $D_{i, t}^{\text {cohort }}$ is a dummy variable which indicates if individual, $i$, belongs to cohort, cohort $_{c-1} \in\left\{G I_{1}, G I_{2}, G S_{1}, G S_{2}, B B_{1}, B B_{2}, G X_{1}, G X_{2}\right\}$, in time period, $t$. For example if individual $i$, observed at time $t$, belongs to the first 10 -years of the $\mathrm{BB}, B B_{1}$, then $D_{i, t}^{\text {cohort }_{5-1}}=1$ and $D_{i, t}^{\text {cohort }_{c-1}}=0 \forall c \neq 5$. The dummy variable $D_{i, t}^{a g e_{a-10}}$ indicates if individual $i$ belongs to the age group age $e_{a-10} \in\{16-24,26-35,36-45,46-55,56-$ $65,65-70\}$, at time period $t$. For example if individual $i$, observed at time $t$, belongs to the age interval $16-24$ then $D_{i, t}^{a g e_{10-10}}=D_{i, t}^{a g e_{0}}=1$ and $D_{i, t}^{a g e_{a-10}}=0 \forall a \neq 10$. The controls for gender, income, education, data collector and time work in a similar way and are denoted with $D_{i, t}^{\text {gender }}, D_{i, t}^{\text {income }}, D_{i, t}^{\text {education }}, D_{i, t}^{\text {datacollector }}$ and $D_{i, t}^{\text {year }}$ respectively. Since we are particularly interested in the MG, we set up the model so that results are relative to individuals born after 1985. For the other variables in equation 1, which are all dummy variables based on categorical variables in the survey, we set the results relative to the highest 
integer value in the domain for each variable, i.e. the highest integer values that the variable can take. The model includes 65 parameter estimates in total. This is a relatively large number of parameters, which in many circumstances may cause OLS to over-fit the data thus inflating the variance of the estimated parameters. However, this is not likely to be an issue in our case as we have 186,150,370,069 and 371,572 observations in our different specifications of equation 1 which vastly exceeds the number of parameters. Table 7 presents the results for the four measures of confidence. Note that time-, gender-, education-, income- and data collectorfixed effects are omitted from the table to save space. ${ }^{\mathrm{vi}}$

Table 7. LSDV Estimations

\begin{tabular}{|c|c|c|c|c|}
\hline & Measure 1 & Measure 2 & Measure 3 & Measure 4 \\
\hline$\alpha$ & $\begin{array}{c}2.34 * * * \\
(0.01)\end{array}$ & $\begin{array}{c}0.54 * * * \\
(0.03)\end{array}$ & $\begin{array}{c}-0.12 * * * \\
(0.03)\end{array}$ & $\begin{array}{c}0.25 * * * \\
(0.04)\end{array}$ \\
\hline $\mathrm{GI}_{1}$ & $\begin{array}{c}-0.15 * * * \\
(0.02)\end{array}$ & $\begin{array}{c}-0.38 * * * \\
(0.04)\end{array}$ & $\begin{array}{c}-0.07 * * \\
(0.04)\end{array}$ & - \\
\hline $\mathrm{GI}_{2}$ & $\begin{array}{c}-0.19 * * * \\
(0.02)\end{array}$ & $\begin{array}{c}-0.38 * * * \\
(0.04)\end{array}$ & $\begin{array}{l}-0.05 \\
(0.03)\end{array}$ & - \\
\hline $\mathrm{GS}_{1}$ & $\begin{array}{c}-0.20 * * * \\
(0.01)\end{array}$ & $\begin{array}{c}-0.33 * * * \\
(0.03)\end{array}$ & $\begin{array}{c}-0.06^{* *} \\
(0.03)\end{array}$ & - \\
\hline $\mathrm{GS}_{2}$ & $\begin{array}{c}-0.21 * * * \\
(0.01)\end{array}$ & $\begin{array}{c}-0.33 * * * \\
(0.03)\end{array}$ & $\begin{array}{c}-0.12 * * * \\
(0.03)\end{array}$ & $\begin{array}{c}-0.30 * * * \\
(0.07)\end{array}$ \\
\hline $\mathrm{BB}_{1}$ & $\begin{array}{c}-0.20 * * * \\
(0.01)\end{array}$ & $\begin{array}{c}-0.28 * * * \\
(0.02)\end{array}$ & $\begin{array}{c}-0.15^{* * * *} \\
(0.02)\end{array}$ & $\begin{array}{c}-0.21 * * * \\
(0.05)\end{array}$ \\
\hline $\mathrm{BB}_{2}$ & $\begin{array}{c}-0.18 * * * \\
(0.01)\end{array}$ & $\begin{array}{c}-0.18 * * * \\
(0.02)\end{array}$ & $\begin{array}{c}-0.16^{* * * *} \\
(0.02)\end{array}$ & $\begin{array}{c}-0.26^{* * *} * \\
(0.04)\end{array}$ \\
\hline $\mathrm{GX}_{1}$ & $\begin{array}{c}-0.11 * * * \\
(0.01)\end{array}$ & $\begin{array}{c}-0.08 * * * \\
(0.02)\end{array}$ & $\begin{array}{c}-0.10 * * * \\
(0.01)\end{array}$ & $\begin{array}{c}-0.23 * * * \\
(0.03)\end{array}$ \\
\hline $\mathrm{GX}_{2}$ & $\begin{array}{c}-0.04 * * * \\
(0.01) \\
\end{array}$ & $\begin{array}{c}0.02 \\
(0.01) \\
\end{array}$ & $\begin{array}{c}-0.03 * * \\
(0.01) \\
\end{array}$ & $\begin{array}{c}-0.16^{* * * *} \\
(0.02)\end{array}$ \\
\hline Age: $16-25$ & $\begin{array}{c}0.27 * * * \\
(0.02)\end{array}$ & $\begin{array}{l}-0.05 \\
(0.04)\end{array}$ & $\begin{array}{c}-0.21 * * * \\
(0.05)\end{array}$ & $-0.15^{* * *}$ \\
\hline Age: $26-35$ & $\begin{array}{c}0.16^{* * * *} \\
(0.01)\end{array}$ & $\begin{array}{c}0.01 \\
(0.03)\end{array}$ & $\begin{array}{c}0.15^{* * *} \\
(0.02)\end{array}$ & $(0.04)$ \\
\hline Age: $36-45$ & $\begin{array}{c}0.10^{* * * *} \\
(0.01)\end{array}$ & $\begin{array}{c}0.09 * * * \\
(0.02)\end{array}$ & $\begin{array}{c}0.24 * * * \\
(0.02)\end{array}$ & $-0.09 * * *$ \\
\hline Age: $46-55$ & $\begin{array}{c}0.07 * * * \\
(0.01)\end{array}$ & $\begin{array}{c}0.09 * * * \\
(0.02)\end{array}$ & $\begin{array}{c}0.18 * * * \\
(0.02)\end{array}$ & $(0.03)$ \\
\hline Age: $56-65$ & $\begin{array}{c}0.02 * * * \\
(0.01)\end{array}$ & $\begin{array}{c}0.03 \\
(0.02)\end{array}$ & $\begin{array}{c}0.09 * * * \\
(0.01)\end{array}$ & $-0.06 * * *$ \\
\hline Age: $65-70$ & $\begin{array}{c}0.00 \\
(0.01)\end{array}$ & $\begin{array}{c}-0.03 * * \\
(0.01)\end{array}$ & $\begin{array}{l}0.02 * * \\
(0.01)\end{array}$ & $(0.02)$ \\
\hline $\mathrm{N}$ & 370,069 & 371,572 & 371,572 & 186,150 \\
\hline Adjusted R-s & 0.26 & 0.05 & 0.02 & 0.09 \\
\hline
\end{tabular}

(***significance at $1 \%$ level, **significance at 5\% level, *significance at $10 \%$ level, robust standard errors, $\mathrm{HAC}(0)$ are presented in parentheses)

The LSDV results that are presented in Table 7 show that the intercept for Measure 1 is greater than 2 and significant at the $1 \%$ level. This means that the MG is on average positive about economic developments. The estimated intercept for Measure 2 is greater than zero and significant at the $1 \%$ level, meaning that the MG is more positive about the future developments of their own personal economic situation than the nationwide economy which indicates that the generation is overconfident. The intercept estimate for Measure 3 is negative 
and significant at the $1 \%$ level, meaning that the MG is on average more positive about the past developments of their personal economic situation than they are about the future state of their personal economic situation. This indicates that the MG is relatively pessimistic about its own future situation, which suggests that the generation is not consistently overconfident about the future relative to the past. The model estimates the intercept in Measure 4 as positive and significant at the $1 \%$ level. This means that the MG is more positive about the future of the nationwide economy than they are about the past developments of the nationwide economy. This indicates that the MG is relatively optimistic about the future situation of the nationwide economy, which suggests that the generation is consistently overconfident about the future relative to the past.

A clear majority of the dummy variable estimates for GI, GS, BB and GX are negative. Generation dummy estimates for Measure 1 are negative and significant for all generations. Generation dummy estimates for Measure 2 are all negative and significant with a majority at the $1 \%$ level with the exception of the last cohort belonging to the GX, which is insignificant. A majority of the generation dummy estimates for Measure 3 are negative, with the exception of the GI. Generation dummy estimates for Measure 4 are all negative and significant at the $1 \%$ level for all generations in the sample. This implies that the MG is more confident and more optimistic than other generations, rendering support for Hypothesis 2.

The regression results speak in favour of Hypothesis 3, as consumer confidence appears to change gradually from one generation to the next. Measures tend to transition from a stable level for the GI and the GS to a new and higher level for the GX and the MG.

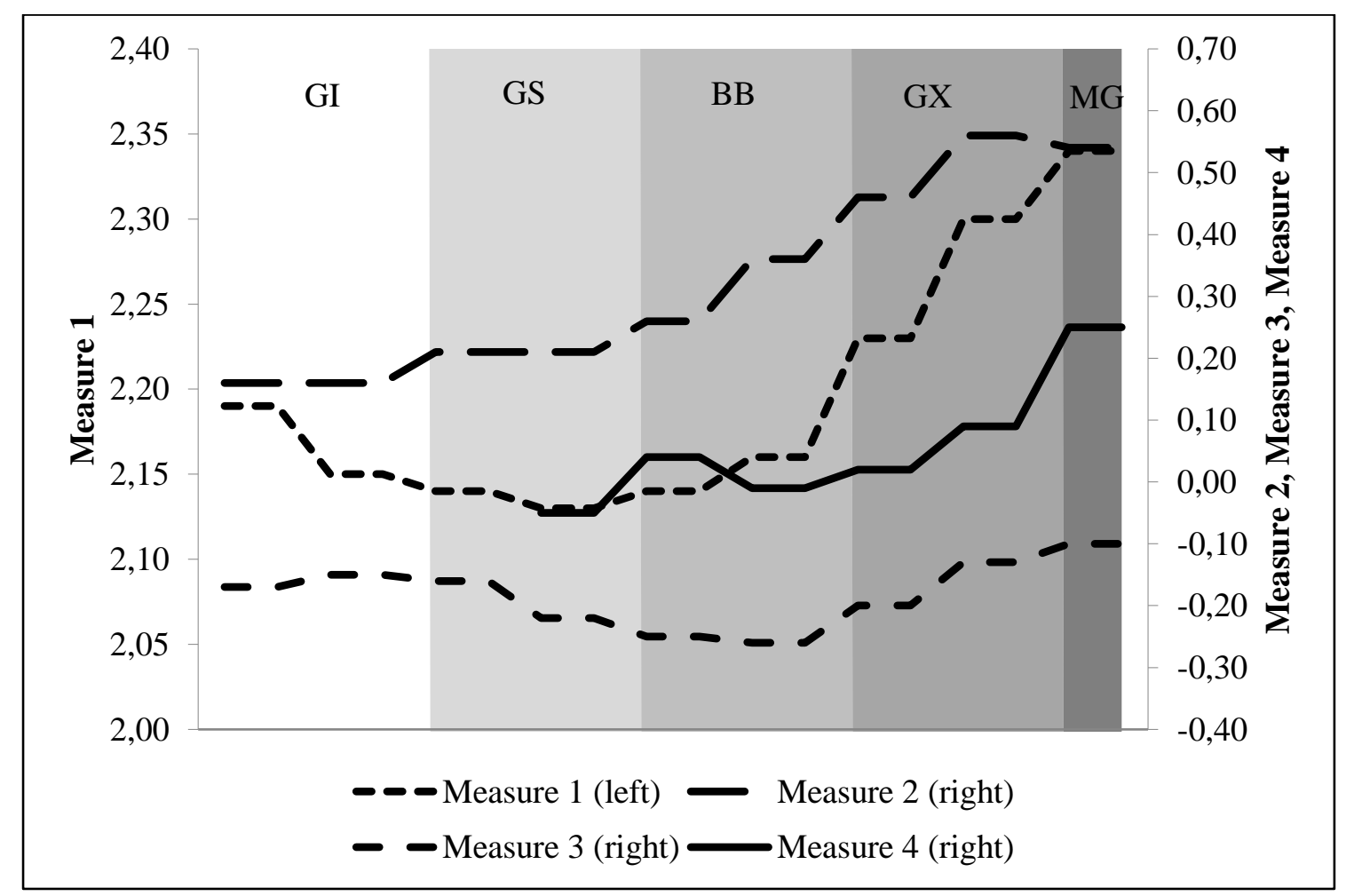

Figure 1. Estimated economic confidence levels

Figure 1 shows that the development of generations' estimated confidence changes gradually across time. Confidence levels in Measure 1 are stable within the GI and GS. An increasing trend starts with the $\mathrm{BB}$ generation and continues with each cohort that follows. Measure 2 is likewise stable for the GI and GS, with an increase starting with the BB which continues steadily for the GX and MG. Development of estimates in Measure 4 appear to start increasing with the GX and then level off with the arrival of the MG. Measure 3, 
however, is stable across generations. To further test if the development of our measures across and between generations is a gradual development, we estimate equation 1 splitting each generation into 4 different groups. These results are very similar to the ones presented in Table 7 which renders more support to Hypothesis 3. The results from the OLS regression are presented in the appendix.

Hypothesis 1 - that the GI, GS and GX are similar in economic confidence - is supported by the results that the GI and GS generations are similar for all confidence measurements. It is, however, rejected in that the GX generation is different from the GI and GS, with confidence levels more similar to the MG generation. The BB generation is also different from the MG generation and more similar to the GI and GS generations, causing us to reject Hypothesis 1.

Hypothesis 4 - that individuals exhibit a life-cycle pattern in economic confidence irrespective of the generation to which they belong - is supported by the results presented in Table 7. All specifications show significant age effects. A life-cycle effect is most prominent for Measure 1, Measure 3 and Measure 4. These measurements show increasing confidence until midlife, which thereafter decreases when individuals approach retirement. This development is most pronounced for Measure 3, where the model estimates a negative and significant effect for ages 16-25. This is reasonable, as many individuals are students and/or still living with their parents during this time of their life and may expect a lower net income in the near future as they move away from home and may thus expect costs to increase disproportionally to their income as their parental economic support decreases and their own income is more or less unchanged. ${ }^{\text {vii }}$ Estimates for ages above 25 are positive and significant, with the largest estimate for the age group 36-45. Ages above 45 are again less optimistic when individuals are nearing retirement age (65 years), with point estimates close to zero for ages 65-70. This indicates that expectations become more stable with age. This is reasonable, as a majority of individuals experience a drop in income as they enter retirement, causing them to expect a worsening of their personal economic situation in the near future.

\section{Robustness checks}

Measure 2, 3 and 4 are ordered categorical variables which represent intervals of unobserved continuous variables. Although it is common to use OLS with a categorical dependent variable, it is theoretically a violation of the Gauss-Markov condition that the residuals are identically and independently normally distributed (McKelvey and Zavoina, 1975; Winship and Mare, 1984). As a robustness check, we thus estimate equation 1 using a multinomial ordered PROBIT which explicitly accounts for the nature of our dependent variables, with the assumption that the unobserved continuous variables which underlie them are normally distributed. The results are presented in Table 8 . viii 
Table 8. Ordered multinomial PROBIT estimates

\begin{tabular}{|c|c|c|c|}
\hline & Measure 2 & Measure 3 & Measure 4 \\
\hline $\mathrm{GI}_{1}$ & $\begin{array}{c}-0.45^{* * *} * \\
(0.05)\end{array}$ & $\begin{array}{l}-0.08^{*} \\
(0.05)\end{array}$ & - \\
\hline $\mathrm{GI}_{2}$ & $\begin{array}{c}-0.46^{* * *} * \\
(0.04)\end{array}$ & $\begin{array}{l}-0.05 \\
(0.04)\end{array}$ & - \\
\hline $\mathrm{GS}_{1}$ & $\begin{array}{c}-0.39 * * * \\
(0.04)\end{array}$ & $\begin{array}{l}-0.07 * \\
(0.04)\end{array}$ & - \\
\hline $\mathrm{GS}_{2}$ & $\begin{array}{c}-0.39 * * * \\
(0.03)\end{array}$ & $\begin{array}{c}-0.15 * * * \\
(0.03)\end{array}$ & $\begin{array}{c}-0.34 * * * \\
(0.08)\end{array}$ \\
\hline $\mathrm{BB}_{1}$ & $\begin{array}{c}-0.34 * * * \\
(0.03)\end{array}$ & $\begin{array}{c}-0.19 * * * \\
(0.03)\end{array}$ & $\begin{array}{c}-0.25 * * * \\
(0.06)\end{array}$ \\
\hline $\mathrm{BB}_{2}$ & $\begin{array}{c}-0.22 * * * \\
(0.02) \\
\end{array}$ & $\begin{array}{c}-0.19 * * * \\
(0.02) \\
\end{array}$ & $\begin{array}{c}-0.3 * * * \\
(0.05) \\
\end{array}$ \\
\hline $\mathrm{GX}_{1}$ & $\begin{array}{c}-0.1 * * * \\
(0.02)\end{array}$ & $\begin{array}{c}-0.12 * * * \\
(0.02)\end{array}$ & $\begin{array}{c}-0.26^{* * * *} \\
(0.03)\end{array}$ \\
\hline $\mathrm{GX}_{2}$ & $\begin{array}{c}0.02 \\
(0.01) \\
\end{array}$ & $\begin{array}{c}-0.04 * * * \\
(0.02) \\
\end{array}$ & $\begin{array}{c}-0.18 * * * \\
(0.02) \\
\end{array}$ \\
\hline Age: $16-25$ & $\begin{array}{l}-0.06 \\
(0.05)\end{array}$ & $\begin{array}{c}-0.28 * * * \\
(0.06)\end{array}$ & $-0.18 * * *$ \\
\hline Age: $26-35$ & $\begin{array}{c}0.01 \\
(0.03)\end{array}$ & $\begin{array}{c}0.18 * * * \\
(0.03)\end{array}$ & $(0.05)$ \\
\hline Age: $36-45$ & $\begin{array}{c}0.11 * * * \\
(0.03)\end{array}$ & $\begin{array}{c}0.29 * * * \\
(0.03)\end{array}$ & $-0.11 * * *$ \\
\hline Age: $46-55$ & $\begin{array}{c}0.11 * * * \\
(0.02)\end{array}$ & $\begin{array}{c}0.22 * * * \\
(0.02)\end{array}$ & $(0.03)$ \\
\hline Age: $56-65$ & $\begin{array}{c}0.03 \\
(0.02)\end{array}$ & $\begin{array}{c}0.11 * * * \\
(0.02)\end{array}$ & $-0.06 * * *$ \\
\hline Age: $65-70$ & $\begin{array}{c}-0.03 * * \\
(0.02)\end{array}$ & $\begin{array}{l}0.03 * * \\
(0.01)\end{array}$ & $(0.02)$ \\
\hline $\mathrm{N}$ & 371,572 & 371,572 & 186,150 \\
\hline
\end{tabular}

Reporting on the results presented in Table 8, we note that the estimated marginal effects are similar to the OLS estimates presented in Table 8 both in magnitude and sign. The OLS results for Measure 1 presented in Table 8 are robust to changes in generation cohorts and estimation method. We attain similar results when we estimate the model with 5-year generational cohorts in order to investigate whether the results are sensitive to further cohort demarcation.

\section{Conclusions}

We test four hypotheses regarding generations' economic confidence: (i) the GI, GS and GX generations are similar, with lower economic confidence than the BB and MG generations; (ii) the MG is more confident about economic developments than all other generations; (iii) economic confidence changes gradually from one generation to the next; and (iv) individuals exhibit a life-cycle pattern in economic confidence, irrespective of the generation to which they belong.

The empirical results support the latter three hypotheses, but not the first hypothesis. Confidence appears to change gradually across generations and predictably across different ages. Although the MG is more confident than most other generations, they are similar to the 
GX in confidence. As expected, the GI and GS are similar, having low confidence in relation to later generations, but they are different, however, from the more confident GX. This result is likely due to the fact that the early-life experiences of the GX are not similar enough to those of the GI and GS. In the same vein, the BB is not similar to the MG in economic confidence, despite both generations growing up during times of economic stability and prosperity. This suggests that generations, although sharing seemingly similar experiences during their formative years, are not necessarily similar in economic confidence.

Overall, our results indicate that the generations according to Howe and Strauss (1997, 2000) do not exist. Instead, the development of economic confidence during the 1900s is more adequately described as a movement from a low level (GI, GS) to a new and higher level (GX, MG) via a transition period (BB). The MG is nevertheless the most confident and overconfident generation in the sample, but the reason for the MG being particularly confident is not, however, likely to come from their unique early-life experiences. It is more likely to come from changes in norms at the societal level. Many developed economies, including Sweden, have experienced increased individualization and decreased influence of traditional norms such as the law of Jante during the second half of the 1900s (Kvidal, 2011; van Raaij, 1993). This may have caused individuals to become more self-centred, narcissistic and thus more overconfident (Cai et al., 2012).

A new and higher level of confidence in the economy may have several consequences. Business cycle dynamics are likely to change as the wave-like behaviour of consumer confidence alters. Outcomes in financial markets may change as the older and less confident generation of financial market participants is being replaced by younger and more overconfident individuals. This may lead to stronger and more frequent asset price bubbles, which are likely to spill over into the real economy, causing recessions. The presence of more overconfident individuals in the economy may, on the other hand, lead to a higher degree of entrepreneurship and more innovation. Such a development shows potential for stronger economic growth.

\section{Acknowledgement}

Funding from the Jan Wallander and Tom Hedelius Foundation is gratefully acknowledged.

\section{References}

Allvin, M. \& Sverke, M. (2000). Do New Generations Imply the End of Solidarity? Swedish Unionism in the Era of Individualisation, Economic and Industrial Democracy, 21, 7195.

Arenius, P. \& Minniti, M. (2005). Perceptual Variables and Nascent Entrepreneurship, Small Business Economics, 24, 233-247.

Arnett, J.J. (2000). Emerging adulthood: A theory of development from the late teens through the twenties, American Psychologist, 55, 469-480.

Ayala-Perez, T. (2019). The digital culture of students of pedagogy specialising in the humanities in Santiago de Chile. Computers and Education, 133, 1-12.

Baek, E. \& DeVaney, S.A. (2004). Assessing the Baby Boomers' Financial Wellness Using Financial Ratios and a Subjective Measure, Family and Consumer Sciences Research Journal, 32, 321-348.

Baker, M. \& Wurgler, J. (2007). Investor Sentiment in the Stock Market, Journal of Economic Perspectives, 21, 129-151. 
Bourke, B. \& Mechler, H.S. (2010). A New Me Generation? The Increasing Self-Interest among Millennial College Students, Journal of College and Character, 11, 2-7.

Bovi, M. (2009). Economic versus psychological forecasting. Evidence from consumer confidence surveys, Journal of Economic Psychology, 30, 563-574.

Brown, S. \& Taylor, K. (2006). Financial Expectations, Consumption and Saving: A Microeconomic Analysis, Fiscal Studies, 27, 313-338.

Burnside, C., Han, B., Hirshleifer, D. and Wang, Y.T. (2011). Investor Overconfidence and the Forward Premium Puzzle, Review of Economic Studies, 78, 523-558.

Cai, H., Kwan, V.S.Y. and Sedikides, K. (2012). A Sociocultural Approach to Narcissism: The Case of Modern China, European Journal of Personality, 26, 529-535.

Caspi, A. \& Roberts, B.W. (2001). Personality Development across the Life Course: The Argument for Change and Continuity, Psychological Inquiry, 12, 49-66.

Chyung, S.Y., Roberts, K., Swanson, I. \& Hankinson, A. (2017). Evidence-Based Survey Design: The Use of a Midpoint on the Likert Scale, Performance Improvement, 56, 1523.

Claessens, S., Dell'Ariccia, G., Igan, D. \& Laeven, L. (2010). Cross-country experiences and policy implications from the global financial crisis, Economic Policy, 4, $267-293$.

Crampton, S.M. and Hodge, J.W. (2009). Generation Y: Unchartered Territory, Journal of Business \& Economics Research, 7, 1-6.

Dey, J.G. \& Pierret, C.R. (2014). Independence for young millennials: moving out and boomeranging back, Monthly Labor Review, 12, U.S. Bureau of Labor Statistics.

Duca, J.V., Muellbauer, J. \& Murphy, A. (2010). Housing markets and the financial crisis of 2007-2009: Lessons for the future, Journal of Financial Stability, 6, 203-217.

Edvinsson, R. (2005). Growth, Accumulation, Crisis: With New Macroeconomic Data for Sweden 1800-2000, Stockholm University, PHD thesis.

Gan, J. (2007). The Real Effects of Asset Market Bubbles: Loan- and Firm-Level Evidence of a Lending Channel, The Review of Financial Studies, 20, 1942-1973.

Gardner, D. \& Macky, K. (2012). Generational Differences: Something Old, Something New, in International Handbooks of Quality-of-Life, Springer, 417-428.

Hershatter, A. \& Epstein, M. (2010). Millennials and the World of Work: An Organization and Management Perspective, Journal of Business Psychology, 25, 211-223.

Hirshleifer, David. (2001). Investor Psychology and Asset Pricing, The Journal of Finance, 4, 1533-1597.

Howe, N. \& Strauss, W. (1997). The Fourth Turning: What the Cycles of History Tell Us about America's Next Rendezvous with Destiny, New York, Broadway Books.

Howe, N. \& Strauss, W. (2000). Millennials rising: The next great generation, New York, Vintage Books.

Kelly, P.J. (2010). Age of Entitlement: How Does Physician Assistant Education Change to Accommodate the Generation Y Student?, The Journal of Physician Assistant Education, 21, 47-51.

Keynes, J.M. (1936). The General Theory of Employment, Interest and Money, London, Macmillan.

Koellinger P., Minniti M. \& Schade C. (2007). "I think I can, I think I can": Overconfidence and entrepreneurial behavior, Journal of Economic Psychology, 28, 502-527.

Krosnick, J.A. \& Fabrigar, L.R. (1997). Designing rating scales for effective measurement in surveys, in L. Lyberg, P. Biemer, M. Collins, E. De Leeuw, C. Dippo, N. Schwarz, and D. Trewin (Eds.). Survey Measurement and Process Quality, 141-164, New York, John Wiley \& Sons.

Kupperschmidt, B.R. (2000). Multi-generation employees: Strategies for effective management, The Health Care Manager, 19, 65-76. 
Kvidal, T. (2011). Tensions of Consumer Individualism, Nordicom Review, 32, 111-124.

Lachmann, L.M. (1943). The Role of Expectations in Economics as a Social Science, Economica, 37, 12-23.

Levenson, A.R. (2010). Millennials and the World of Work: An Economist's Perspective, Journal of Business Psychology, 25, 257-264.

Ljungberg, J. \& Nilsson, A. (2009). Human capital and economic growth: Sweden 18702000, Cliometrica, 3, 71-95.

Malmendier, U. \& Nagel, S. (2011). Depression Babies: Do Macroeconomic Experiences Affect Risk Taking?, The Quarterly Journal of Economics, 126, 373-416.

Malmendier, U. and Nagel, S. (2016). Learning from Inflation Experiences, The Quarterly Journal of Economics, 131, 53-87.

Malmendier, U., Tate, G. \& Yan, J. (2011). Overconfidence and Early-Life Experiences: The Effect of Managerial Traits on Corporate Financial Policies, The Journal of Finance, $66,1687-1733$.

Mannheim, K. (1952). The Problem of Generations, Essays on the Sociology of Knowledge, London: RKP (first published 1923).

Manski, C. (2004). Measuring expectations, Econometrica, 72, 1329-1376.

Martin, C.A. \& Tulgan, B. (2001). Managing Generation Y, New Haven, HRD Press.

Matsusaka, J. and Sbordone, A. (1995). Consumer confidence and economic fluctuations, Economic Inquiry, 33, 296-318.

McKelvey, R.D. \& Zavoina W. (1975). A statistical model for the analysis of ordinal level dependent variables, Journal of Mathematical Sociology, 4, 103-120.

Meisel, M.K., Ning, H., Campbell, W.K. \& Goodie, A.S. (2016). Narcissism, Overconfidence, and Risk Taking in U.S. and Chinese Student Samples, Journal of Cross-Cultural Psychology, 47, 385-400.

Mills, K.L. (2014). Effects of Internet use on the adolescent brain: despite popular claims, experimental evidence remains scarce, Trends in Cognitive Sciences, 18, 385-387.

Moretti, E. (2011). Social Learning and Peer Effects in Consumption: Evidence from Movie Sales, Review of Economic Studies, 78, 356-393.

Muth, J. F. (1961). Rational Expectations and the Theory of Price Movements, Econometrica, 29, 315-335.

Myers, K.K. \& Sadaghiani, K. (2010). Millennials in the Workplace: A Communication Perspective on Millennials, Organizational Relationships and Performance', Journal of Business Psychology, 25, 225-238.

Nga, J.K.H. \& Yien, L.K. (2013). The influence of personality trait and demographics on financial decision making among Generation Y, Young Consumers, 14, 230-243.

Palmqvist, S. \& Strömberg, L. (2004). Households' inflation opinions - a tale of two surveys, Sveriges Riksbank Economic Review, 4, 23-42.

Pilcher, J. (1994). Mannheim's Sociology of Generations: An Undervalued Legacy, The British Journal of Sociology, 45, 481-495.

Schaefer, P.S., Williams, C.C., Goodie, A.S. \& Campbell, W.K. (2004). Overconfidence and the Big Five, Journal of Research in Personality, 38, 473-480.

Schaie, K.W. (1965). A general model for the study of developmental problems, Psychological Bulletin, 64, 92-107.

Schewe, C.D., Debevec, K., Madden, T.J., Diamond, W.D., Parment, A. \& Murphy, A. (2013). "If You've Seen One, You've Seen Them All!" Are Young Millennials the Same Worldwide?, Journal of International Consumer Marketing, 25, 3-15.

Schrand, C.M \& Zechman, S.L.C. (2012). Executive overconfidence and the slippery slope to financial misreporting, Journal of Accounting and Economics, 53, 311-329. 
Schularick, M. \& Taylor, A.M. (2012). Credit Booms Gone Bust: Monetary Policy, Leverage Cycles, and Financial Crises, 1870-2008, American Economic Review, 102, 1029-1061.

Schuman, H. \& Scott, J. (1989). Generations and Collective Memories, American Sociological Review, 54, 359-381.

Scott, J. (2000). Is it a different world to when you were growing up? Generational effects on social representations and child-rearing values, The British Journal of Sociology, 51, 355-376.

Smola, K.W. \& Sutton, C.D. (2002). Generational differences: revisiting generational work values for the new millennium, Journal of Organizational Behavior, 23, 363-382.

Srivastava, S., John O.P., Gosling S.D. \& Potter J. (2003). Development of personality in early and middle adulthood: Set like plaster or persistent change?, Journal of Personality and Social Psychology, 84, 1041-1053.

Stewart, A.J. \& Healy, J.M. (1989). Linking Individual Development and Social Changes, American Psychological Association, 44, 1, 30-42.

Taylor, M. \& McNabb, R. (2007). Business Cycles and the Role of Confidence: Evidence for Europe, Oxford Bulletin of Economics and Statistics, 69, 185-208.

Twenge, J.M. (2009). Generational changes and their impact in the classroom: Teaching Generation Me, Medical Education, 43, 398-405.

Twenge, J.M., Campbell, S.M., Hoffman, B.J. \& Lance, C.E. (2010). Generational Differences in Work Values: Leisure and Extrinsic Values Increasing, Social and Intrinsic Values Decreasing, Journal of Management, 36, 1117-1142.

van Raaij, F. (1993). Postmodern Consumption, Journal of Economic Psychology, 14, 541563.

Winship, C. \& Mare, R.D. (1984). Regression Models with Ordinal Variables, American Sociological Review, 49, 512-525. 


\section{Appendix}

Table 8. LSDV Estimations Using 5-year Generational Cohorts

\begin{tabular}{|c|c|c|c|c|}
\hline & Measure 1 & Measure 2 & Measure 3 & Measure 4 \\
\hline \multirow[b]{2}{*}{$\alpha$} & $2.45 * * *$ & $0.48 * * *$ & $-0.17 * * *$ & 0.12 \\
\hline & $(0.02)$ & $(0.04)$ & $(0.04)$ & (0.07) \\
\hline \multirow{2}{*}{$\mathrm{GI}_{1}$} & $-0.36 * * *$ & $-0.29 * * *$ & -0.06 & 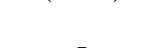 \\
\hline & $(0.03)$ & $(0.08)$ & $(0.07)$ & - \\
\hline \multirow{2}{*}{$\mathrm{GI}_{2}$} & $-0.37 * * *$ & $-0.29 * * *$ & -0.07 & \\
\hline & $(0.03)$ & $(0.06)$ & $(0.06)$ & - \\
\hline \multirow{2}{*}{$\mathrm{GI}_{3}$} & $-0.41 * * *$ & $-0.29 * * *$ & -0.04 & \\
\hline & $(0.02)$ & $(0.06)$ & $(0.05)$ & - \\
\hline \multirow{2}{*}{$\mathrm{GI}_{4}$} & $-0.44 * * *$ & $-0.3 * * *$ & -0.02 & \\
\hline & $(0.02)$ & $(0.05)$ & $(0.05)$ & - \\
\hline \multirow[b]{2}{*}{$\mathrm{GS}_{1}$} & $-0.43^{* * *}$ & $-0.29 * * *$ & -0.03 & \\
\hline & $(0.02)$ & $(0.05)$ & $(0.05)$ & - \\
\hline \multirow{2}{*}{$\mathrm{GS}_{2}$} & $-0.43 * * *$ & $-0.24 * * *$ & -0.02 & \\
\hline & $(0.02)$ & $(0.05)$ & $(0.05)$ & - \\
\hline \multirow{2}{*}{$\mathrm{GS}_{3}$} & $-0.41 * * *$ & $-0.24 * * *$ & -0.05 & \\
\hline & $(0.02)$ & $(0.04)$ & $(0.04)$ & - \\
\hline \multirow{2}{*}{$\mathrm{GS}_{4}$} & $-0.40 * * *$ & $-0.24 * * *$ & $-0.08 * *$ & -0.19 \\
\hline & $(0.02)$ & $(0.04)$ & $(0.04)$ & $(0.12)$ \\
\hline \multirow{2}{*}{$\mathrm{BB}_{1}$} & $-0.38 * * *$ & $-0.23 * * *$ & $-0.11 * * *$ & \\
\hline & $(0.02)$ & $(0.04)$ & $(0.04)$ & - \\
\hline \multirow{2}{*}{$\mathrm{BB}_{2}$} & $-0.37 * * *$ & $-0.22 * * *$ & $-0.14 * * *$ & -0.16 \\
\hline & $(0.02)$ & $(0.03)$ & $(0.03)$ & $(0.1)$ \\
\hline \multirow{2}{*}{$\mathrm{BB}_{3}$} & $-0.34 * * *$ & $-0.16 * * *$ & $-0.1 * * *$ & -0.1 \\
\hline & $(0.01)$ & $(0.03)$ & $(0.03)$ & $(0.08)$ \\
\hline \multirow{2}{*}{$\mathrm{BB}_{4}$} & $-0.30 * * *$ & $-0.09 * * *$ & $-0.11 * * *$ & $-0.16^{* *}$ \\
\hline & $(0.01)$ & $(0.03)$ & $(0.03)$ & $(0.07)$ \\
\hline \multirow{2}{*}{$\mathrm{GX}_{1}$} & $-0.28 * * *$ & $-0.09 * * *$ & $-0.13 * * *$ & $-0.13^{* *}$ \\
\hline & $(0.01)$ & $(0.03)$ & $(0.02)$ & $(0.06)$ \\
\hline \multirow{2}{*}{$\mathrm{GX}_{2}$} & $-0.25 * * *$ & 0.02 & $-0.08 * * *$ & $-0.12 * *$ \\
\hline & $(0.01)$ & $(0.02)$ & $(0.02)$ & $(0.05)$ \\
\hline \multirow{2}{*}{$\mathrm{GX}_{3}$} & $-0.15 * * *$ & -0.01 & -0.03 & $-0.12 * *$ \\
\hline & $(0.01)$ & $(0.02)$ & $(0.02)$ & $(0.05)$ \\
\hline \multirow{2}{*}{$\mathrm{GX}_{4}$} & $-0.12 * * *$ & $0.16^{* * * *}$ & 0.01 & -0.03 \\
\hline & $(0.01)$ & $(0.02)$ & $(0.02)$ & $(0.04)$ \\
\hline \multirow[b]{2}{*}{$\mathrm{MG}_{1}$} & $-0.07 * * *$ & $0.04 * *$ & $0.03 *$ & $-0.07 * *$ \\
\hline & $(0.01)$ & $(0.02)$ & $(0.02)$ & $(0.03)$ \\
\hline \multirow{2}{*}{$\mathrm{MG}_{2}$} & $-0.04 * * *$ & $0.2 * * *$ & $0.13 * * *$ & $0.25 * * *$ \\
\hline & $(0.01)$ & $(0.02)$ & $(0.02)$ & $(0.03)$ \\
\hline \multirow{2}{*}{ Age: 16-25 } & $0.12 * * *$ & -0.05 & $-0.22 * * *$ & \\
\hline & $(0.02)$ & $(0.05)$ & $(0.05)$ & $-0.16 * *$ \\
\hline A ge. 26-35 & $0.03 *$ & 0.01 & $0.13 * * *$ & $(0.07)$ \\
\hline Age: $20-35$ & $(0.02)$ & $(0.04)$ & $(0.03)$ & \\
\hline & 0.01 & $0.1 * * *$ & $0.23 * * *$ & \\
\hline Age: $36-45$ & $(0.01)$ & $(0.03)$ & $(0.03)$ & $-0.09 *$ \\
\hline & 0.02 & $0.09 * * *$ & $0.18 * * *$ & $(0.05)$ \\
\hline Age: 46-55 & $(0.01)$ & $(0.03)$ & $(0.02)$ & \\
\hline Age: 56-65 & 0.00 & 0.02 & $0.09 * * *$ & \\
\hline Age: 50-0د & $(0.01)$ & $(0.02)$ & $(0.02)$ & $-0.06^{*}$ \\
\hline A ge. 65-70 & 0.00 & $-0.03 *$ & 0.01 & $(0.03)$ \\
\hline Age: 0J-/0 & $(0.01)$ & $(0.02)$ & $(0.01)$ & \\
\hline $\mathrm{N}$ & 370,069 & 371,572 & 371,572 & 186,150 \\
\hline Adjusted R-sq. & 0.26 & 0.05 & 0.02 & 0.09 \\
\hline
\end{tabular}

(***significance at $1 \%$ level, **significance at $5 \%$ level, *significance at $10 \%$ level, robust standard errors, $\mathrm{HAC}(0)$ are presented in parentheses) 


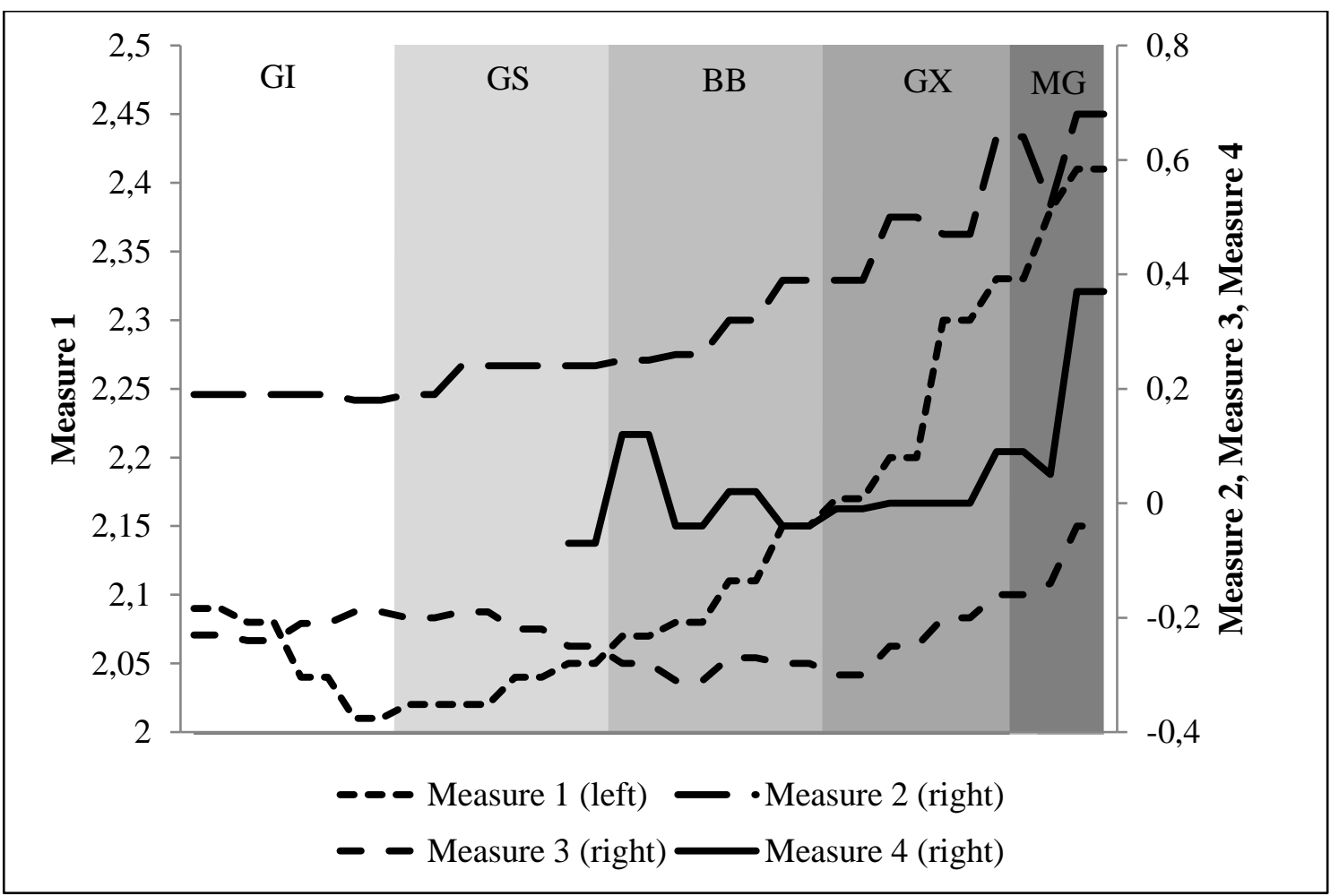

Figure 2. Estimated Economic Confidence Levels using 5-year generational cohorts

\footnotetext{
${ }^{\text {i }}$ The MG experienced the Great Recession of 2008/2009, which impacted the Swedish economy to a lesser extent than it impacted many other developed economies (see, for example, Claessens et al., 2010).

ii Schewe et al. (2013) name the fall of the Berlin Wall in 1989, the emergence of a united Europe, the sinking of the ship Estonia in 1994, and the Tsunami in Thailand in 2004 as important events.

iii See Palmqvist and Strömberg (2004) for more background information on the survey.

${ }^{\text {iv }}$ We deliberately exclude Q4 from this measure as it is included in the survey only from 1994 onwards.

${ }^{\vee}$ The model controls for the data collector, as previous research has shown that there are statistically significant differences in the replies from respondents depending on the body that collected the data (Palmqvist and Strömberg, 2004).

${ }^{v i}$ The full regression tables are available upon request.

vii See for example Dey and Pierret (2014) for an analysis of determinants of Millennials' decision to move away from home.

viii As the multinomial ordered PROBIT is not defined for negative values, we have added 3 to all of the observations in these measures. This ensures that our measures are ordered from 1 to 5 as opposed to from -2 to 2 , which is the case in the OLS regressions presented in Table 7.
} 